\title{
Indicators of terrestrial biogenic hydrocarbon contamination and linear alkyl benzenes as land-base pollution tracers in marine sediments
}

\author{
A. D. Syakti - L. Asia · F. Kanzari $\cdot$ H. Umasangadji • \\ S. Lebarillier · B. Oursel · C. Garnier • L. Malleret • \\ Y. Ternois $\cdot$ G. Mille $\cdot$ P. Doumenq
}

Received: 9 February 2013/Revised: 24 July 2013/ Accepted: 6 November 2013/Published online: 20 November 2013

(C) Islamic Azad University (IAU) 2013

\begin{abstract}
Aliphatics (n-alkanes) and polycyclic aromatic hydrocarbons (PAHs) were measured in surface sediments collected from 12 sampling points (P1-P12) of sewage discharge to the sea from the wastewater treatment plant of Cortiou (France). Total $n$-alkanes and PAHs concentrations ranged from 34 to 2,155 and 696 to $10,700 \mu \mathrm{g} \mathrm{kg}^{-1}$, respectively. Some specific hydrocarbon indexes suggested that terrestrial biogenic inputs are predominant compared to marine sources and that pyrolytic sources derived from wood and biomass combustion contribute to PAHs in the surface sediments. Total linear alkyl benzenes in Cortiou sediments ranged from 42.9 to $502.3 \mu \mathrm{g} \mathrm{kg}^{-1}$. Low internal and external (I/E) isomers ratio (P0) suggests that inadequately treated sewage is discharged into the marine
\end{abstract}

Electronic supplementary material The online version of this article (doi:10.1007/s13762-013-0430-x) contains supplementary material, which is available to authorized users.

\section{A. D. Syakti $(\bowtie)$}

Fisheries and Marine Sciences Department, Jenderal Soedirman University, Kampus Perikanan Unsoed Karangwangkal, J1 dr. Suparno, Purwokerto 53123, Indonesia

e-mail: agungsyakti@chemist.com

A. D. Syakti · L. Asia · F. Kanzari · H. Umasangadji ·

S. Lebarillier · L. Malleret · G. Mille · P. Doumenq

LCE, FRE 3416, équipe MPO. Europôle de l'Arbois, Aix

Marseille Université, Bâtiment Villemin, BP 80,

13545 Aix-En-Provence Cedex 4, France

B. Oursel · C. Garnier

Laboratoire PROTEE, Université du Sud Toulon Var, BP 20132,

83957 La Garde, France

Y. Ternois

C E R E G E/UMR 6635. Europôle de l'Arbois, Aix Marseille Université, Avenue Louis Philibert, BP 80,

13545 Aix-En-Provence Cedex 4, France environment while some environmental processes might change I/E ratios during transport seaward (P1-P12). The high contaminant levels followed by the cumulative concentration of several compounds may lead to elevated toxicity levels in the sediments.

Keywords Organic contaminants $\cdot n$-Alkanes · Polycyclic aromatic hydrocarbons - Linear alkyl benzenes . Environmental monitoring · Wastewater treatment discharge

\section{Introduction}

The Bay of Marseille is one of the most urbanized sites in the Mediterranean region. A large number of industrial and domestic wastes are discharged into the bay, which contains considerable quantities of pollutants that enter the marine environment via various routes. Primary potential pollution sources are the urban wastewater treatment plant (WWTP) "Géolide," with an average discharge of $4 \mathrm{~m}^{3} \mathrm{~s}^{-1}$, the Marseille channel and runoff from the $\mathrm{Hu}-$ veaune River, which passes through many industrial sites. During periods of intense rain, excess rainfall is channeled through Cortiou. The site studied in this research is located in the center of the "Calanque National Park" and encompasses the Friou archipelago, Plane, the Marseilleveyre islands and Cap Croisette up to Green Island. The National Park, which was established in June 2012, is the first suburban national park in Europe. Land- and seabased sources of petroleum hydrocarbon pollution in this area have been identified in previous studies (Mille et al. 2007; Asia et al. 2009). However, to the best of our knowledge, there are no published data for linear alkyl benzenes (LABs) in this specific area. Moreover, even if 
LABs are present in small amounts in some crude oils, the presence of various alkyl benzenes in sediments is not directly related to contamination by petrogenic or pyrolytic sources but rather is due to their use as precursors in the industrial synthesis of linear alkyl benzene sulfonate (LAS) detergents (Ishiwatari et al. 1983; Mungray and Kumar 2009).

Here, our goals are to characterize the occurrence and extent of (1) petroleum hydrocarbon pollution in Cortiou sediments, particularly $n$-alkane and polyaromatic hydrocarbons (PAHs) pollution, and (2) "sewage tracer" compounds, such as LABs, as by-products of LAS detergents, which are the most widely used anionic surfactants (Léon et al. 2000). Another goal of this study is to determine whether municipal water discharge is responsible for the presence of these pollutants by determining the concentrations and distributions of individual $n$-alkanes, 16 EPA priority PAHs and LABs in surface sediments of the Cortiou in relation to the carbon content and organic carbon in the sediment (Hinga 2003; Rico-Rico et al. 2009). This study was performed in 2010-2011 in the Environmental Chemistry Laboratory, Aix-Marseille University, France.

\section{Materials and methods}

\section{Chemicals}

SupraSolv grade (Merck, Darmstadt, Germany) solvents such as acetone (AC), dichloromethane (DCM) and $n$ hexane (HEX) were purchased from VWR International (Fontenay Sous Bois, France). Acetonitrile of high-performance liquid chromatograph (HPLC) grade (Merck) and water purified with a Milli-Q system (Millipore, Bedford, MA, USA) were used throughout the liquid chromatography analysis.

The reference standard mixture containing 16 US EPA priority PAHs, namely naphthalene $(\mathrm{Na})$, acenaphthylene (Acy), acenaphthene (Ace), fluorene $(\mathrm{F})$, phenanthrene (Phe), anthracene (Ant), fluoranthene (Fl), pyrene (Pyr), benzo(a)anthracene (B[a]Ant), chrysene (Chr), benzo(b)fluoranthene $(\mathrm{B}[\mathrm{b}] \mathrm{Fl}), \quad$ benzo(k)fluoranthene $(\mathrm{B}[\mathrm{k}] \mathrm{Fl})$, benzo(a)pyrene (B[a]Pyr), indeno (1,2,3-cd) pyrene (Ind), dibenzo(a,h)anthracene ( $\mathrm{dB}[\mathrm{ah}] \mathrm{Ant})$ and benzo(ghi) perylene $(\mathrm{B}[\mathrm{ghi}] \mathrm{P})$, at concentration levels between 100 and $2,000 \mathrm{mg} \mathrm{mL}^{-1}$ in methanol/dichloromethane $(1: 1 ; \mathrm{v}-\mathrm{v})$ was obtained from Supelco (Bellefonte, PA, USA). Labeled $n$-alkane (n-nonadecane- $\left.\mathrm{d}_{40}\right)$ and 1-phenylnonane were purchased from Sigma-Aldrich, St. Louis, MO, USA. Standard working solutions were diluted by DCM. A standard certified reference material (harbor marine sediment HS-5) was obtained from Laboratory of the Government Chemist (LGC) Promochem.
Fontainebleau sand was provided by Carlo Erba reagents (Milan, Italy). Alumina, silica-gel 60 (200-300 mesh) and anhydrous sodium sulfate $\left(\mathrm{Na}_{2} \mathrm{SO}_{4}\right)$ were purchased from VWR International. The alumina and silica-gel silica was deactivated with $5 \%$ water (w:w), and $\mathrm{Na}_{2} \mathrm{SO}_{4}$ was baked for $48 \mathrm{~h}$ at $550{ }^{\circ} \mathrm{C}$ before use. Analytical reagent grade of glucose and $\mathrm{H}_{3} \mathrm{PO}_{4}$ were purchased from Fisher Scientific. $\mathrm{NaHCO}_{3} / \mathrm{Na}_{2} \mathrm{CO}_{3}$ was supplied from Shimadzu.

\section{Sample collection}

As shown in Fig. 1, sediments from 12 sampling points (three independent subsamples per point; P1-P12) were collected in front of the WWTP sewer outfall of CortiouMarseille, France. One additional point has been collected in the wastewater treatment sewerage canal (P0). Surface sediment samples were collected with a sediment grab sampler (Shiptex; Wildco Inc, USA) and PVC core samplers (100 mm diameter) using Scuba equipment on March 21 and June 23, 2010. The sampling points were collected in a line perpendicular to the coastline (direction $237^{\circ} \mathrm{N}$ ) starting from the sewer outfall (with low salinity) and moving out toward the sea, up to the limit of WWTP sewage discharge influence. All sediment samples were freeze-dried, sieved using a 2-mm mesh, homogenized and stored at $-18{ }^{\circ} \mathrm{C}$ prior to analysis.

\section{Sample extraction and analysis}

The sample extraction and analysis were conducted according to Kanzari et al. (2012) and Syakti et al. (2013). Briefly, $10 \mathrm{~g}$ of freeze-dried sediments was transferred to a precleaned cellulose extraction thimble and extracted using a Soxhlet extractor apparatus for $16 \mathrm{~h}$ with a $200 \mathrm{~mL}$ mixture of DCM and HEX (1:1, v/v). Prior to extraction, nonadecane- $\mathrm{d}_{40}$ was added to the samples as an internal standard (IS) for $n$-alkane quantification. All or part of the extractable organic matter (EOM), depending on the initial weight, was dissolved in $n$-hexane and applied to a $50 \%$ alumina/50\% silica ( $8 \mathrm{~g}$ of each, both deactivated with $\left.5 \% \mathrm{H}_{2} \mathrm{O}\right)$ chromatography column $(30 \times 1 \mathrm{~cm})$. The saturated fraction (F1) was first eluted with $30 \mathrm{~mL}$ of HEX. Elution with $20 \mathrm{~mL}$ of HEX/DCM (9:1) and $40 \mathrm{~mL}$ of HEX/DCM (4:1) was combined to yield the aromatic fraction (F2). Sulfur interference was removed by shaking the extract with copper powder previously reduced with diluted hydrochloric acid $(0.1 \mathrm{M})$ (Blumer 1957). A labeled $n$-alkane ( $n$-nonadecane- $\left.\mathrm{d}_{40}\right)$ was added to each sample and the matrix blank prior to extraction as surrogate to assess the overall procedural recovery. In this study, $n$ alkane surrogate recoveries were 98 to $102 \%$. Concerning PAHs, an HS-5 certified sediment was analyzed to evaluate the extraction accuracy. Reproducibility estimated for 


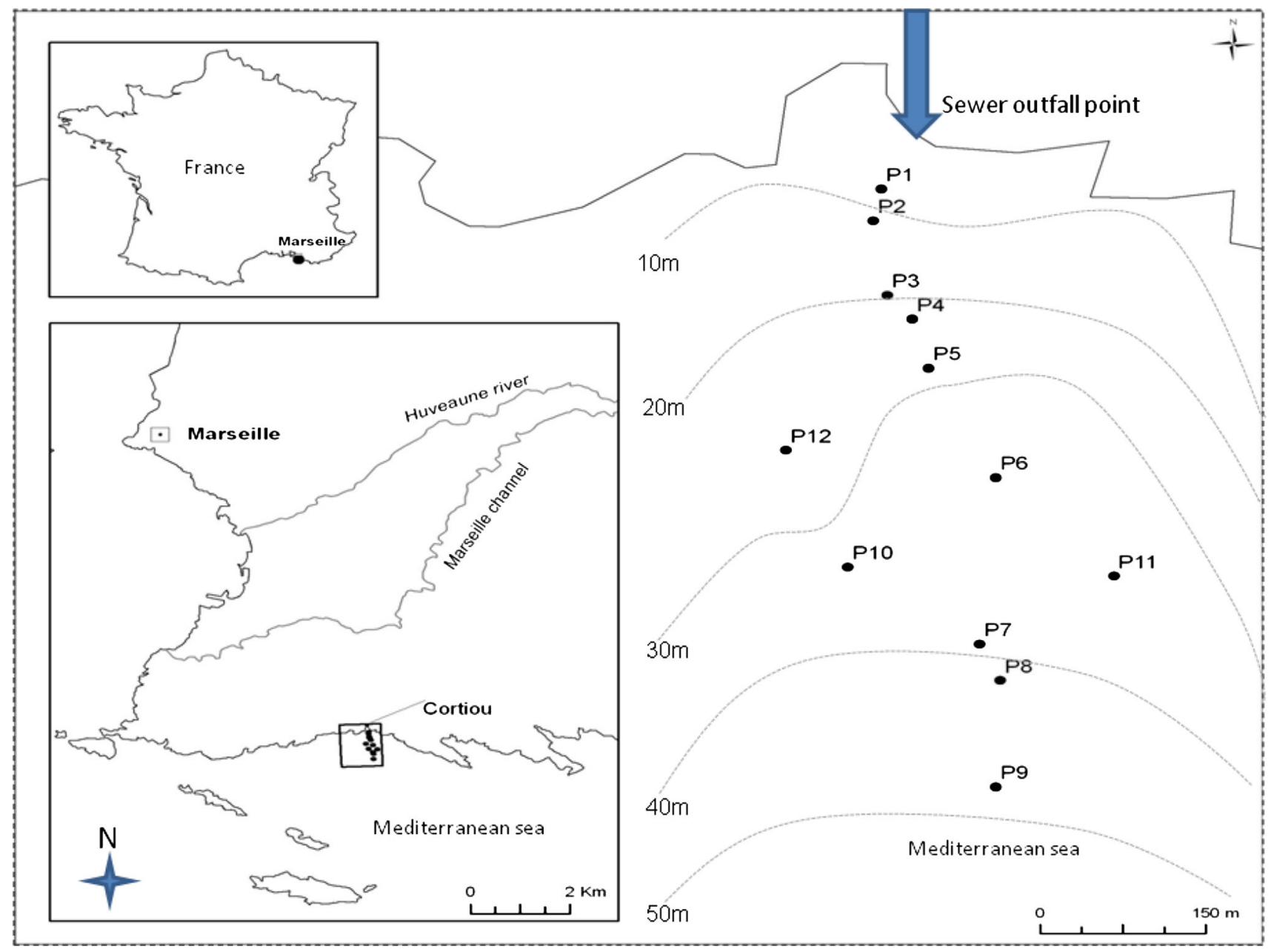

Fig. 1 Site location and sampling stations. Dot lines indicate the isobath of 10-m contours

PAHs on triplicate samples was $>90 \%$. Each fraction was evaporated on a rotary evaporator and under a gentle stream of nitrogen, and the dry residue was weighed (microbalance, Perkin-Elmer AD2Z). The sum of the aliphatic and the aromatic fractions gave the total hydrocarbon content (THC). F1 was diluted in HEX, and the $n$ alkanes present were separated by capillary gas chromatography (GC) under the following equipment: GC Autosystem XL Perkin Elmer chromatograph with on-column injection and a Perkin Elmer Elite-XLB column (30 $\mathrm{m} \times 0.25 \mathrm{~mm}$ ID $\times 0.25 \mu \mathrm{m}$ film thickness). Helium was used as the carrier gas at a constant rate of $1 \mathrm{~mL} \mathrm{~min}^{-1}$. The temperature was programmed from 70 to $285{ }^{\circ} \mathrm{C}\left(5^{\circ} \mathrm{C} \min ^{-1}\right)$ and then held for $30 \mathrm{~min}$. The mass spectrometer was operated in the electron impact ionization (EI) mode $(70 \mathrm{eV})$ and simultaneously scanned in both Full Scan and Selected Ion Monitoring (SIM) modes. LAB identification relied on both retention times and characteristic ions. The $91 \mathrm{~m} / \mathrm{z}$ ion was used for quantification, and the 105 and $119 \mathrm{~m} / \mathrm{z}$ ions were used for confirmation with 1-phenylnonane as internal standard. Conventionally, these isomers are described using the form $n$ - $\mathrm{C}_{m}$-LAB, where $n=$ the position of the benzene ring and $m=$ the number of carbon atoms in the aliphatic chain. Aromatic hydrocarbons (PAHs) contained in F2 were analyzed using a Prostar (Varian, Palo Alto, CA, USA) HPLC equipped with a thermally controlled autosampler and a programmable fluorescence detector (HPLC-PFD). Excitation/ emission time windows for the fluorescence detector are described in Fig. 2. The injection vial and the analytical column were maintained at 10 and $35^{\circ} \mathrm{C}$, respectively, for all analyses. The separations were carried out using a reverse-phase $\mathrm{C}_{18}$ column $(250 \mathrm{~mm} \times 4.6 \mathrm{~mm} \times 5 \mu \mathrm{m}$, ChromSpher 5PAH, Varian) protected by a $\mathrm{C}_{18}$ guard column (10 mm $\times 3 \mathrm{~mm}, 5 \mu \mathrm{m}$, Chromguard). Aliquots of $20 \mu \mathrm{L}$ were injected, and the flow rate was held at $1.2 \mathrm{~mL} \mathrm{~min}^{-1}$ for a total run time of $55 \mathrm{~min}$. The data were acquired and processed using the Galaxie ${ }^{\mathrm{TM}}$ software 


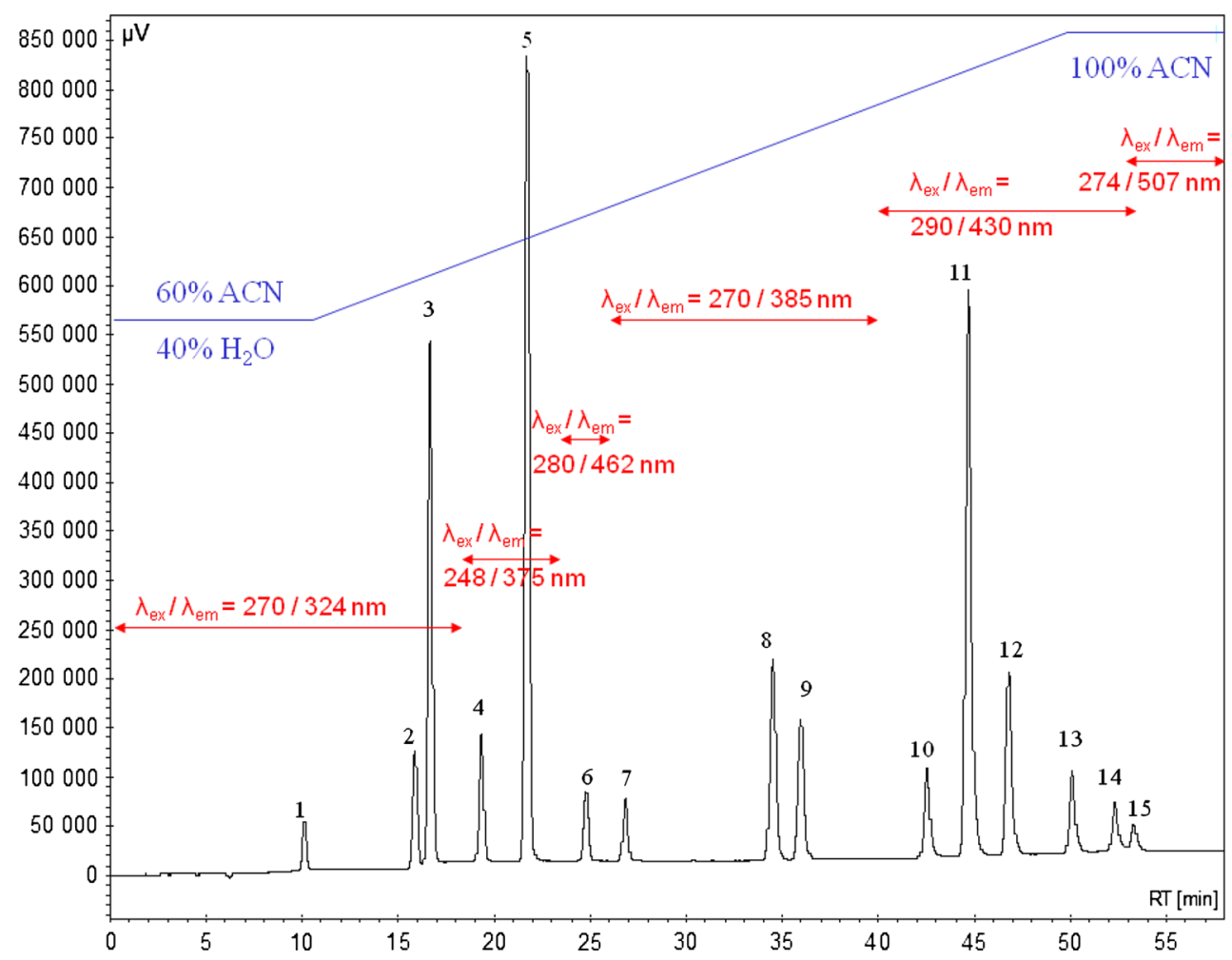

Fig. 2 HPLC-PFD chromatogram obtained from Cortiou sediments. Peak identities are (1) naphthalene (Na), (2) acenaphthene (Ace), (3) fluorene (F), (4) phenanthrene (Phe), (5) anthracene (Ant), (6) fluoranthene (Fl), (7) pyrene (Pyr), (8) Benzo(a)anthracene (B[a]Ant), (9) chrysene (Chr), (10) benzo(b)fluoranthene (B[b]Fl), (11) benzo(k)fluoranthene $(\mathrm{B}[\mathrm{k}] \mathrm{Fl})$, (12) benzo(a)pyrene (B[a]Pyr), (13)

package (Varian). The total carbon (TC) content was determined using the high-temperature $\left(900{ }^{\circ} \mathrm{C}\right)$ catalytic oxidation method with IR detection of $\mathrm{CO}_{2}$ (Benner and Strom 1993). The inorganic carbon content was determined after addition of $\mathrm{H}_{3} \mathrm{PO}_{4}$ at $200{ }^{\circ} \mathrm{C}$ followed by IR quantification of $\mathrm{CO}_{2}$, calibrated using $\mathrm{NaHCO}_{3} / \mathrm{Na}_{2} \mathrm{CO}_{3}$. The total organic carbon (TOC) content was calculated by subtracting the TC content from the inorganic carbon content. All data in this work concerning contaminants concentrations in sediment $\left(\mu \mathrm{g} \mathrm{kg}^{-1}\right)$ were expressed related to dry weight sediment.

\section{Statistical analysis}

The analysis of variance (ANOVA) and linear regression were employed to compare differences in $\sum n$-alkane, $\sum$ PAHs and $\sum$ LABs with the physicochemical properties (EOM, TC and TOC) in the surface sediments of Cortiou and to explore correlations between these parameters. A $p$ value of 0.05 or less was regarded as being significant for all the tests. The statistical analyses were implemented using the SigmaPlot for Windows ${ }^{\circledR}$ version 11.0 (Systat Software, Inc., wpcubed, GmbH, Germany). indeno (1,2,3-cd) pyrene (Ind), (14) dibenzo(a,h)anthracene (dB[ah]Ant) and (15) benzo(ghi) perylene $(\mathrm{B}[\mathrm{ghi}] \mathrm{P})$. The excitation $\left(\lambda_{\mathrm{ex}}\right)$ and emission $\left(\lambda_{\mathrm{eM}}\right)$ wavelength program to determine individual PAHs and gradient elution program using solvent with fluorescence detection following liquid-liquid A (Acetonitrile) and solvent B (Water)

\section{Results and discussion}

n-Alkane occurrence in Cortiou sediments

Table 1 summarizes petroleum hydrocarbon contamination in Cortiou surface sediments. As shown, EOM can be used as an indicator of organic material input in the environment. The EOM concentrations ranged from 352 to $7,525 \mathrm{mg} \mathrm{kg}^{-1}$ with an arithmetic mean of $1,739 \mathrm{mg} \mathrm{kg}^{-1}$. These values are significantly higher than those previously reported close to the Cortiou area, which ranged from 40 to $300 \mathrm{mg} \mathrm{kg}^{-1}$ (Mille et al. 2007; Asia et al. 2009). This elevated range of EOM may indicate surface sediment that is highly polluted with organic materials but is not necessarily contaminated with hydrocarbons. Indeed, THC/EOM ranged from 60.5 to $84.6 \%$ (Table 1), compared to $52 \%$ for sediments chronically contaminated with petroleum hydrocarbons (Mille et al. 2007). For the latter sediments, F1 fractions represent approximately $80 \%$ of the total hydrocarbons and are markedly higher (1.9-4.9 times) than F2 fractions. Total $n$ alkanes (Table 2) ranged from 342 to $2,155 \mu \mathrm{g} \mathrm{kg}^{-1}$, except for P9 $\left(34 \mu \mathrm{g} \mathrm{kg}^{-1}\right)$. Several authors have used indexes to assess the origins of hydrocarbons based on geochemical 
Table 1 Gravimetric analysis, total carbon (TC) and total organic carbon (TOC) content data for Cortiou sediments

\begin{tabular}{|c|c|c|c|c|c|c|c|c|c|c|}
\hline $\begin{array}{l}\text { Cortiou } \\
\text { points }\end{array}$ & $\begin{array}{l}\text { EOM } \\
\left(\mathrm{mg} \mathrm{kg}^{-1}\right)\end{array}$ & $\begin{array}{l}\mathrm{F} 1 \\
\left(\mathrm{mg} \mathrm{kg}^{-1}\right)\end{array}$ & $\begin{array}{l}\mathrm{F} 2 \\
\left(\mathrm{mg} \mathrm{kg}^{-1}\right)\end{array}$ & $\begin{array}{l}\text { THC } \\
\left(\mathrm{mg} \mathrm{kg}^{-1}\right)\end{array}$ & $\begin{array}{l}\text { THC/EOM } \\
(\%)\end{array}$ & $\begin{array}{l}\text { F1/THC } \\
(\%)\end{array}$ & $\begin{array}{l}\text { F2/THC } \\
(\%)\end{array}$ & $\mathrm{F} 1 / \mathrm{F} 2$ & $\begin{array}{l}\mathrm{TC} \\
(\%)\end{array}$ & $\begin{array}{l}\text { TOC } \\
(\%)\end{array}$ \\
\hline P0 & 352.2 & 196.7 & 99 & 262.7 & 74.6 & 74.9 & 25.1 & 3.0 & 11.2 & 0.8 \\
\hline P1 & 554 & 316.8 & 79.2 & 396.0 & 71.4 & 80.0 & 20.0 & 4.0 & 8.1 & 1.9 \\
\hline $\mathrm{P} 2$ & 355 & 186.9 & 28.0 & 215.0 & 60.5 & 87.0 & 13.0 & 6.7 & 8.0 & 0.5 \\
\hline P3 & 853 & 431.0 & 155.2 & 586.2 & 68.7 & 73.5 & 26.5 & 2.8 & 8.4 & 1.1 \\
\hline P4 & 1,553 & 844.7 & 252.3 & $1,097.1$ & 70.6 & 77.0 & 23.0 & 3.3 & 7.9 & 2.6 \\
\hline P5 & 1,476 & 847.6 & 219.0 & $1,066.7$ & 72.3 & 79.5 & 20.5 & 3.9 & 7.2 & 1.7 \\
\hline P6 & 730 & 475.4 & 139.3 & 614.8 & 84.3 & 77.3 & 22.7 & 3.4 & 8.2 & 3.1 \\
\hline P7 & 7,525 & $5,209.3$ & $1,157.6$ & $6,366.9$ & 84.6 & 81.8 & 18.2 & 4.5 & 11.6 & 7.4 \\
\hline P8 & 3,706 & $2,354.6$ & 540.4 & $2,895.0$ & 78.1 & 81.3 & 18.7 & 4.4 & 12.9 & 8.8 \\
\hline P9 & 2,819 & $1,952.4$ & 400.0 & $2,352.4$ & 83.4 & 83.0 & 17.0 & 4.9 & 10.5 & 4.9 \\
\hline P10 & 390 & 178 & 93.2 & 271.2 & 69.6 & 65.6 & 34.4 & 1.9 & 7.9 & 1.3 \\
\hline P11 & 416 & 238.9 & 79.6 & 318.6 & 76.6 & 75.0 & 25.0 & 3.0 & 8.1 & 0.8 \\
\hline P12 & 496 & 278.3 & 95.7 & 373.9 & 75.4 & 74.4 & 25.6 & 2.9 & 8.4 & 1.6 \\
\hline
\end{tabular}

$\mathrm{TC}$ and TOC are expressed from $\mathrm{mg} \mathrm{C} \mathrm{mg}^{-1}$ of dry sediment with an accuracy of $\pm 0.1 \mathrm{mg} \mathrm{C}$

$E O M$ extractable organic matter, F1 saturated hydrocarbon fraction, $F 2$ polycyclic aromatic hydrocarbon fraction, THC total hydrocarbon content, TC total carbon, TOC total organic carbon

markers such as $\sum n$-alkane $/ n \mathrm{C}_{16}$, low/high molecular weight (LMW/HMW), the Carbon Preference Index (CPI), the natural $n$-alkanes ratio (NAR), the terrigenous/aquatic ratio (TAR) and the simple ratio of $n \mathrm{C}_{29} / n \mathrm{C}_{17}$ (Bourbonniere and Meyers 1996; Mille et al. 2007; Asia et al. 2009). According to these authors, petroleum-contaminated samples displayed $\sum n$-alkane $/ n \mathrm{C}_{16}$ values $<15$, while biological samples had values higher than 50. The application of this ratio to Cortiou sediments (Table 2) showed a predominant biogenic input, as evidenced by the high values $(>200)$. Furthermore, the LMW/HMW ratio confirmed this trend with values largely below 0.2 . Such ratio values have been reported for biogenic sources issued from sedimentary bacteria, marine animals and higher plants (Jeng 2006; Syakti et al. 2013). The CPI indicates the ratio between odd- and even-numbered $n$-alkanes (Budzinski et al. 1997). In the range $\mathrm{C}_{11}-\mathrm{C}_{35}$, CPI values close to one are characteristic of crude oils and petroleum hydrocarbons (Volkman et al. 2008). For most stations, CPI values ranged from 1.8 to 4.6 (average 2.6), with a predominance of $n \mathrm{C}_{25}, n \mathrm{C}_{27}, n \mathrm{C}_{29}, n \mathrm{C}_{31}$ and $n \mathrm{C}_{33} n$-alkanes confirming a biogenic input, presumably released during plant wax degradation (Volkman et al. 2008). CPI values $<1$ were measured at station P9, showing a weathered profile of aliphatic hydrocarbons (Asia et al. 2009; Micic et al. 2010). As previously proposed by Mille et al. (2007), the NAR was used to roughly estimate the proportions of natural and petroleum $n$-alkanes. Values from 0.3 to 0.6 were observed, indicating biogenic sources such as higher terrestrial plants or marine plants, rather than the zero values displayed by petroleum hydrocarbons and crude oils (Kanzari et al. 2012; Wagener et al. 2012). Another index used to discriminate terrestrial from marine inputs is the
TAR (Bourbonniere and Meyers 1996), the ratio of longchain odd-numbered $n$-alkanes $\left(n \mathrm{C}_{27}+n \mathrm{C}_{29}+n \mathrm{C}_{31}\right)$ to short-chain odd-numbered $n$-alkanes $\left(n \mathrm{C}_{15}+n \mathrm{C}_{17}+\right.$ $n \mathrm{C}_{19}$ ). For this index, values ranging from 4.8 to 40.4 were observed, characteristic of important terrigenous inputs (Fig. 3a). Moreover, since $n-\mathrm{C}_{29}$ is abundant in land plants and $n-\mathrm{C}_{17}$ is prominent in marine organisms, the ratio of these two alkanes reflects the relative contributions of allochthonous and autochthonous hydrocarbons to the sediment. Thus, they were used to discriminate between terrestrial and marine inputs (Bourbonniere and Meyers 1996; Sikes et al. 2009). A value of approximately 1 for this ratio indicates marine sources. Cortiou sediments yielded values between 4 and 87 , clearly indicting the predominance of terrestrial sources (Fig. 3a).

\section{PAHs}

According to Baumard et al. (1998), sedimentary PAHs levels can be characterized as low, moderate, high and very high when total PAH levels (of the 16 EPA priority PAHs) are in the ranges of $0-100,100-1,000,1,000-5,000$ and $>5,000 \mu \mathrm{g} \mathrm{kg} \mathrm{kg}^{-1}$, respectively. A PAH level below $100 \mu \mathrm{g} \mathrm{kg}^{-1}$ is indicative of sediment with low pollution, whereas values higher than $1,000 \mu \mathrm{g} \mathrm{kg}^{-1}$ correspond to chronically polluted industrialized areas or harbors. In this work, total PAH concentrations varied from 696 to $10,699 \mu \mathrm{g} \mathrm{kg}^{-1}$ with an arithmetical mean of $3,621 \mu \mathrm{g}$ $\mathrm{kg}^{-1}$, corresponding to sediments with pollution in the upper-middle range. Aromatic fractions of sedimentary hydrocarbons were dominated by PAHs with four to five condensed aromatic rings, such as fluoranthene, 


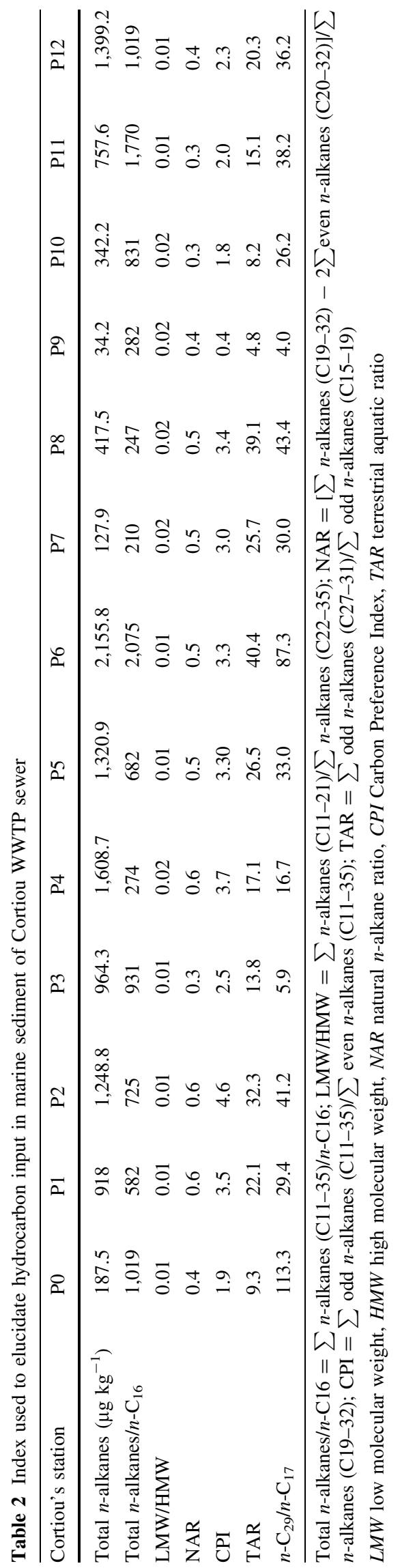

benzo[b]fluoranthene, benzo[a]pyrene, chrysene and benzo[a]anthracene, with average concentrations of 589, 486, 480, 443 and $361 \mu \mathrm{g} \mathrm{kg}^{-1}$, respectively (Table 3). Other PAHs containing four to six condensed rings, such as pyrene, benzo[g,h,i]perylene, benzo[a]fluoranthene, indeno(1,2,3-cd)pyrene and dibenzo[a,h]anthracene, were found with average concentrations of 336, 250, 232, 201 and $44 \mu \mathrm{g} \mathrm{kg}^{-1}$, respectively. Except for phenanthrene, whose average concentration was $176 \mu \mathrm{g} \mathrm{kg}^{-1}$ (Table 3), aromatic fractions were characterized by low concentrations of two to three condensed rings, such as naphthalene, acenaphthene, fluorene and anthracene, which were found at concentrations $<15 \mu \mathrm{g} \mathrm{kg}^{-1} \mathrm{dw}$. Such features may reflect pyrolytic sources derived from biogenic and/or petrogenic input. Because the area studied is located near Marseille, with its urban/suburban agglomeration and industries, industrial and vehicle emissions are possible sources of PAHs. A first attempt to determine possible sources of PAHs can be made using the occurrences of dominant PAHs, i.e., fluoranthene, benzo[a]anthracene and chrysene. In this study, fluoranthene varied from 93 to $1,743 \mu \mathrm{g} \mathrm{kg}^{-1}$. The high concentrations of fluoranthene were attributed to pyrolytic origin, as reported in some studies mentioning the use of fluoranthene as an indicator of combustion related to vehicle engine sources (diesel or gasoline) (Yunker et al. 2002; Deng et al. 2013; Inengite et al. 2013; Liu et al. 2013). Furthermore, benzo[a]anthracene, which ranged from 58 to $1,289 \mu \mathrm{g}$ $\mathrm{kg}^{-1}$, has also been used by many authors to characterize areas impacted by traffic emissions (Fromme et al. 2004). Chrysene levels ranged from 90 to $1,580.2 \mu \mathrm{g} \mathrm{kg}^{-1}$. Previous studies considered chrysene as an indicator of "burning" emissions, such as residential heating, waste incinerators and traffic (Fromme et al. 2004; Asia et al. 2009; Liu et al. 2013). In addition, some studies demonstrated the absence of chrysene in petroleum sources. Page et al. (1999) found low concentrations of chrysene in diesel and crude oil compared with other PAHs. The area studied is located in the South of France, near many sites that have been particularly affected by repeated fires (Vernoux et al. 2011). Leachates due to rain and river runoff may help pyrolytic PAHs from forest fires reach the Cortiou zone. Through numerous examples in the literature, possible sources of PAHs can be evaluated by calculation of abundance ratios of diagnostic PAHs (Mille et al. 2007; Wang et al. 2011). As frequently reported, a Phe/ Ant ratio of $<10$ indicates a pyrolytic origin, while a ratio above 10 indicates a petrogenic origin (Olivella et al. 2006; Deng et al. 2013). The results of this study discriminated between petrogenic (P1-P6, P8, P10 and P12) and pyrolytic (P7, P9 and P11) inputs, as shown in Table 3. A possible explanation for this concern was recent river runoff and landleaching contamination by petroleum hydrocarbons released by the Cortiou treatment plant. However, some authors stated that the Phe/Ant ratio is not a good indicator for 
Fig. 3 GC-MS total ionic current of the saturated hydrocarbon fractions (station P2) with biogenic terrestrial input. UCM unresolved complex mixture (a). SIM fragmentogram using tropylium ion $(\mathrm{m} / \mathrm{z}=91)$ of saturated hydrocarbon fractions; $\mathrm{n}$ and $\mathrm{m}$ indicate alkyl chain lengths on both sides of LAB phenyl groups. IS internal standard (1phenylnonane) (b)

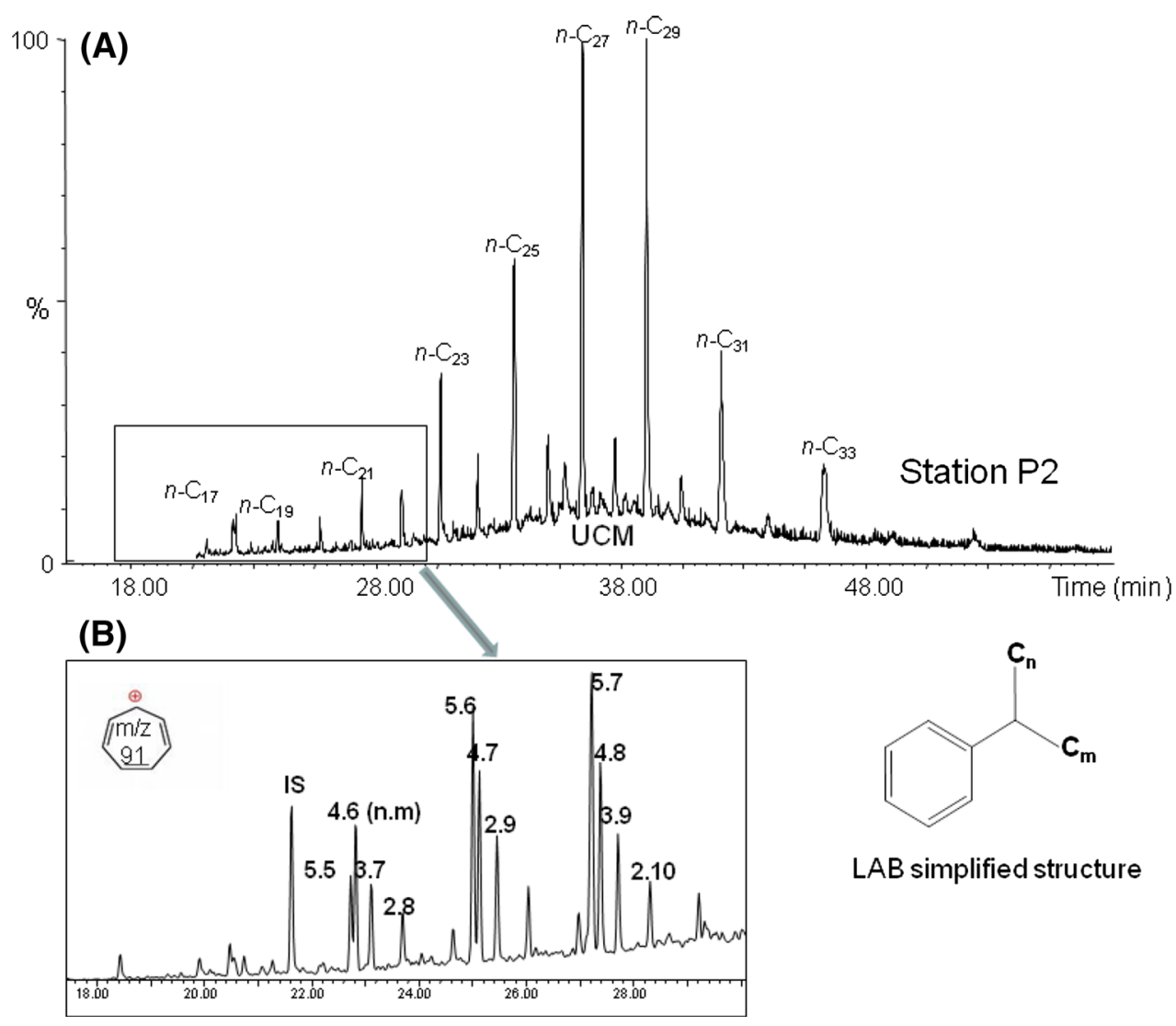

tracing the sources of PAHs because the selective degradation of anthracene (Schutzendubel et al. 1999) during transport may change the value of the ratio (Tao et al. 2006, 2007). Consequently, trends shown by Phe/Ant ratios need to be confirmed using other diagnostic ratios.

In view of the literature, Fl/Pyr can also be used to distinguish between pyrolytic and petroleum origins (Budzinski et al. 1997). A value $<1$ indicates a petroleum origin, while a value $>1$ suggests pyrolytic contamination (Wang et al. 2011). In this study, the Fl/Pyr ratio varied from 1 to 7 with an arithmetic mean of 1.9, undoubtedly indicating pyrolytic sources (Table 3 ), except in the case of P9 (Fl/Pyr $=0.9)$.

Figure 4 presents a 2D ternary diagram plot of $\mathrm{Fl} / \sum 202$, $\mathrm{B}$ [a]Ant/ $\sum 228$ and IP/ $\sum 276$. As proposed by Budzinski et al. (1997), a ratio of $\mathrm{Fl} / \sum 202<0.4$ is generally characteristic of petrogenic sources (oil, diesel and coal), a ratio between 0.4 and 0.5 is consistent with liquid fossil fuel (crude oil and vehicle) combustion, and a ratio over 0.5 is generally found in kerosene, grass, coal and wood combustion and creosote. Moreover, a ratio of $\mathrm{B}[\mathrm{a}] \mathrm{Ant} / \sum 228$ $<0.2$ implies petroleum sources, a value between 0.35 and 0.7 reflects biogenic combustion, and a value close to 0.9 indicates coal or smelters. Finally, an IP/ $\sum 276$ ratio lower than 0.2 is characteristic of petroleum, while a ratio of between 0.2 and 0.5 is consistent with petroleum combustion; moreover, a ratio higher than 0.5 is characteristic of grass/wood/coal combustion (Hartmann et al. 2004). As a benchmark, P0 was considered mixed petrogenic and pyrolytic origins (Fig. 4). Considering all of the respective diagnostic ratios together (Fig. 4), most sediment samples from Cortiou were projected to be in the pyrolytic zone with significant contribution from land-based biomass combustion. This result confirms the previous interpretation based on the Fl/Pyr ratio (Table 3). Despite the presence of steel, iron and aluminum industries in the surrounding area $(<50 \mathrm{~km})$, no $\mathrm{B}[\mathrm{a}] \mathrm{Ant} / \mathrm{2228}$ value over 0.8 , which is characteristic of coal or smelters, was observed. In addition, in many studies, indeno[1,2,3-cd]pyrene and benzo[ghi]perylene have been used as markers of automobile emissions (Harkov et al. 1984; Hartmann et al. 2004). In this study, the absolute concentrations of benzo[ghi]perylene and indeno[1,2,3-cd]pyrene were important, ranging from 30 to $1,070 \mu \mathrm{g} \mathrm{kg}^{-1}$ and from 26 to $662 \mu \mathrm{g} \mathrm{kg}^{-1}$, respectively. Indeed, a plot of IP/ $\sum 276$, which is (IP + BghiP), revealed a signature ratio found between 0.6 and 0.8 , indicating biogenic combustion (P1-P12).

\section{LABs}

During industrial sulfonation processes for LAS synthesis, 1-3\% of LABs remain unreacted (Gledhill et al. 1991). 


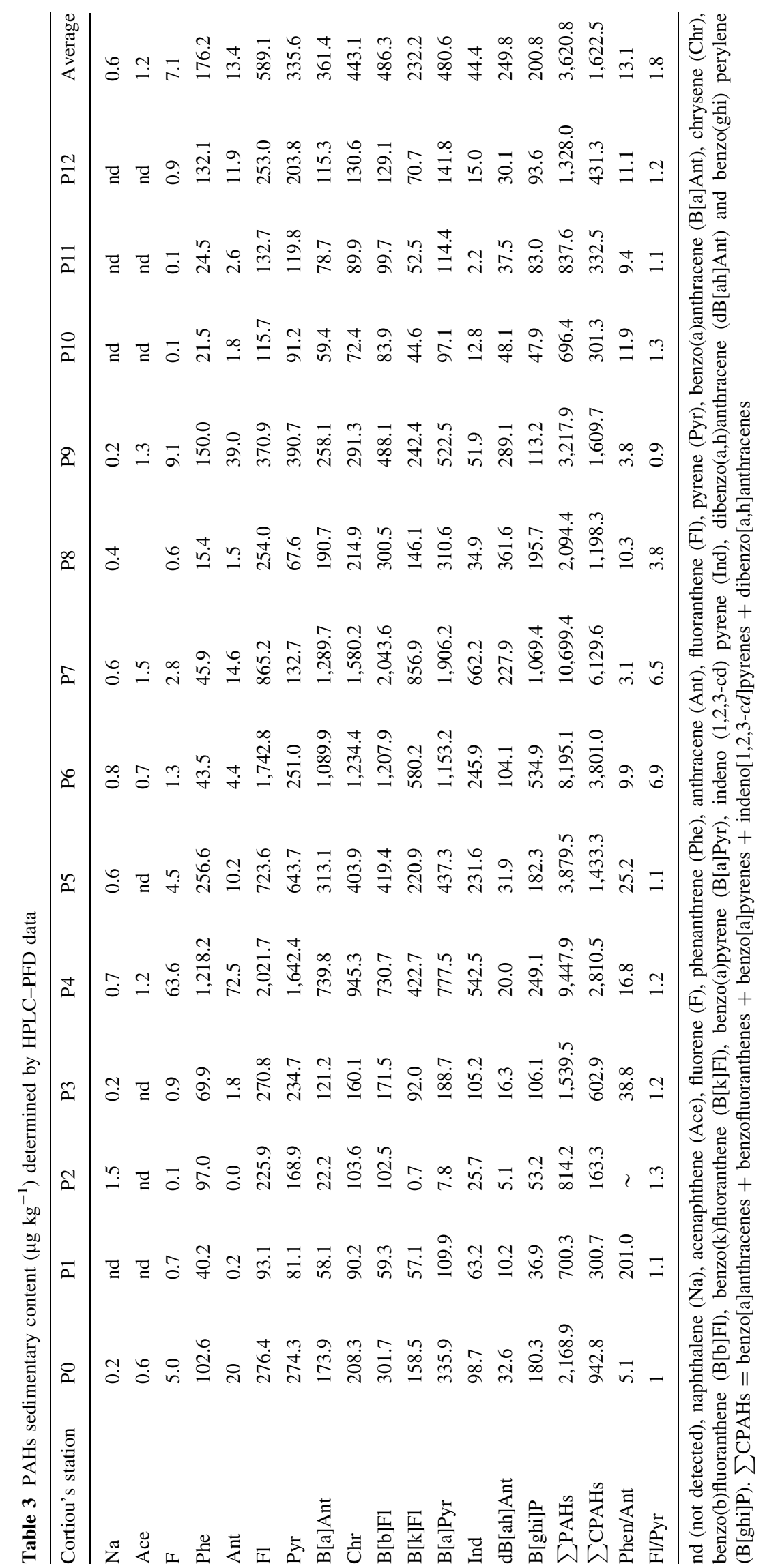


Thus, LABs are considered to be tracer residues for cleaners and detergents in the environment; in addition, they have been proposed as molecular tracers for wastewater entering coastal marine environments wherever LABs are being used and released (Gustafsson et al. 2001). The concentrations of the total LABs (in $\mu \mathrm{g} \mathrm{kg}^{-1}$ ) measured at each sampling point are shown in Table 4. Typical chromatograms' simplified structure of LABs is presented in Fig. 3b. No mass spectrometric interference with tetrapropylene-based alkyl benzenes $(\mathrm{m} / \mathrm{z}=105$ and 119$)$ has been recorded for LABs $(\mathrm{m} / \mathrm{z}=91$ and 105) (Eganhouse and Pontolillo 2008). Table 4 shows LAB levels in Cortiou sediments ranging from 42.9 to $502.3 \mu \mathrm{g} \mathrm{kg}^{-1}$. Compared to levels found in many developed countries with WWTPs, the concentrations of total LABs found in this study are rather low. For instance, Murray et al. (1987) showed that LABs in Australian coastal sediments ranged from 10 to $19,400 \mu \mathrm{g} \mathrm{kg}^{-1}$. Extremely high concentrations of over $10,000 \mu \mathrm{g} \mathrm{kg}^{-1}$ were observed in sediments from Jakarta, Indonesia (Isobe et al. 2004), and were attributed to the absence of WWTPs. Three LAB homologs were found in Cortiou sediments, with 11 different resolved isomers (Table 4). Technical formulations of commercial detergents contain $10-15,25-35,25-35,15-30$ and $0-5 \%$ of $\mathrm{C}_{10}, \mathrm{C}_{11}, \mathrm{C}_{12}, \mathrm{C}_{13}$ and $\mathrm{C}_{14}$ homologs, respectively (Cavalli et al. 1993). Furthermore, in Europe, more than $98 \%$ of $\mathrm{C}_{10}-\mathrm{C}_{13}$ homolog LABs are used as the main components of commercial detergent formulations, predominantly containing $\mathrm{C}_{11}$ and $\mathrm{C}_{12}$ (HERA 2007; Gordon et al. 2009). We observed higher concentrations of linear alkyl benzenes with 12 carbon atoms $\left(\mathrm{C}_{12}-\mathrm{LAB}\right)$, followed by $\mathrm{C}_{10^{-}}$ $\mathrm{LAB}$ and $\mathrm{C}_{11}-\mathrm{LAB}$, accounting for an average of $44.9,28.3$ and $26.7 \%$ of the total LABs, respectively. The linear alkyl chains typically have $10-13$ carbon units, with approximate ratios of $\mathrm{C}_{10} / \mathrm{C}_{11} / \mathrm{C}_{12} / \mathrm{C}_{13}$ being 3/30/33/24, with an average carbon number near 11.6 (Cavalli et al. 1993; Viguri et al. 2002; HERA 2007). LAS environmental fingerprints previously detected in aquatic environmental samples contained $\mathrm{C}_{10} / \mathrm{C}_{11} / \mathrm{C}_{12} / \mathrm{C}_{13}$ at $45: 30: 23: 2$ with an average carbon number of 10.8 (Cavalli et al. 1993). In this study, a ratio of $\mathrm{C}_{10} / \mathrm{C}_{11} / \mathrm{C}_{12} / \mathrm{C}_{13}$ of $25.1 / 25.4 / 45.5 / 0$ was observed, with an average carbon number of 11.2. The predominance of $\mathrm{C}_{12}$-LAB in this study was in agreement with the finding of the previous study (Gustafsson et al. 2001; Rico-Rico et al. 2009). The predominance of $\mathrm{C}_{12^{-}}$ LAB $(34 \%)$ has also been reported by Eganhouse and Sherblom (2001) in municipal WWTP discharge combined with sewer effluents near Boston Harbor. Furthermore, as shown in Table 4, the overall values reveal a removal of odd-numbered alkyl chain LABs. For instance, only traces of $\mathrm{C} 13 \mathrm{LABs}$ under the quantitation limit were detected. The absence of $\mathrm{C}_{13}$-LABs and the slight reduction in the $\mathrm{C}_{11}$-LAB proportion might be due to a selective microbial degradation of the odd-numbered alkyl chain homolog. A supporting argument for such condition is that LABs biodegradation is initiated by an $\omega$-oxidation of the alkyl chain followed by successive cleavage of $\mathrm{C} 2$ fragments ( $\beta$-oxidation), facilitating microbial attack on odd-numbered alkyl chains (HERA 2007). For $\mathrm{C}_{13}$-LAB, such an occurrence is consistent with previous studies, which have demonstrated that the long-chain LABs are more susceptible to biodegradation than the shorter ones (Eganhouse and Sherblom 2001; Eganhouse and Pontolillo 2008). LABs are manufactured in large-scale industrial processes by alkylating benzene with linear mono-olefins or alkyl halides such as chloroparaffins using $\mathrm{HF}$ or $\mathrm{AlCl}_{3}$ as the alkylation catalyst, with average proportions of the homolog isomers 2-, 3-, 4-, 5- and 6-phenyl of 23, 17.5, 17, 21 and $21.5 \%$, respectively (Cavalli et al. 1993). This study found a $\mathrm{C}_{12}$ isomer distribution of 28.7, 23.1, 14.4 and $10.1 \%$ (by weight) for the 5-, 4-, 3- and $2-\mathrm{C}_{12}$, respectively (Table 4). The presence of $\mathrm{nC}_{12}$ isomers was confirmed based on the occurrence of diagnostic ions (at $\mathrm{m} / \mathrm{z} 91+(\mathrm{n} \times 14)$ and $91+((\mathrm{m}-\mathrm{n}) \times 14))$. The absence of the 6- $\mathrm{C}_{12}$ isomer, which has not been previously reported, is most likely a consequence of biodegradation processes that are faster for homologs having an $m$ number of twice their $n$ number (such as $6-\mathrm{C}_{12}-\mathrm{LAB}$ ).

Calculation of the ratios between the internal (I) and external (E) isomers of LABs is useful (Bayona et al. 1986). External isomers are defined as isomers whose phenyl substitution positions are near the terminal end of the alkyl chain. External isomers (phenyl in position 2, 3 or 4 on the alkyl chain) are more susceptible to microbial attack than internal isomers (Eganhouse and Sherblom 2001). Therefore, the $\mathrm{I} / \mathrm{E}$ ratio is proposed by some authors to be an indicator of the extent of LAB degradation (Bayona et al. 1986; Gustafsson et al. 2001; Gordon et al. 2009). In this study, $\mathrm{I} / \mathrm{E}$ values varied from 0.04 to 0.73 with an arithmetic mean of 0.53 , while $\mathrm{I} / \mathrm{E}$ for $\mathrm{P} 0$ was about 0.31 (Table 4). Thus, few external isomers of the LAB were degraded, indicating incomplete degradation performance in the WWTP. Gustafsson et al. (2001) found that $\mathrm{I} / \mathrm{E}$ ratios decreased with increasing distance from the source $(\sim 6)$ to offshore $(<1)$ in Boston Harbor. Luo et al. (2008) found that I/E ratios in sediments collected far away from the source were lower than those in sediments collected in a coastal area adjacent to the source. In this work, samples collected at stations P7-9 had lower I/E ratios. Such ratio value can be explained by WWTP discharges containing high organic material, leading to a faster burial of LABs ( $\mathrm{K}_{\mathrm{ow}}$ ranged from 7.45 to 8.19 ) and thereby reducing the relative importance of aerobic degradation. Alternatively, anaerobic degradation may occur, resulting in no change in I/E ratios (Viguri et al. 2002). Even there is an improvement of the low $\mathrm{I} / \mathrm{E}$ ratios in the Cortiou 
Fig. 4 Ternary diagram differentiation of $\mathrm{PAH}$ origin using a plot of $\mathrm{Fl} / \sum 202$, $\mathrm{B}[\mathrm{a}]$ Ant $/ \sum 228$ and of IP/ (IP + BghiP). The respective ratios were normalized

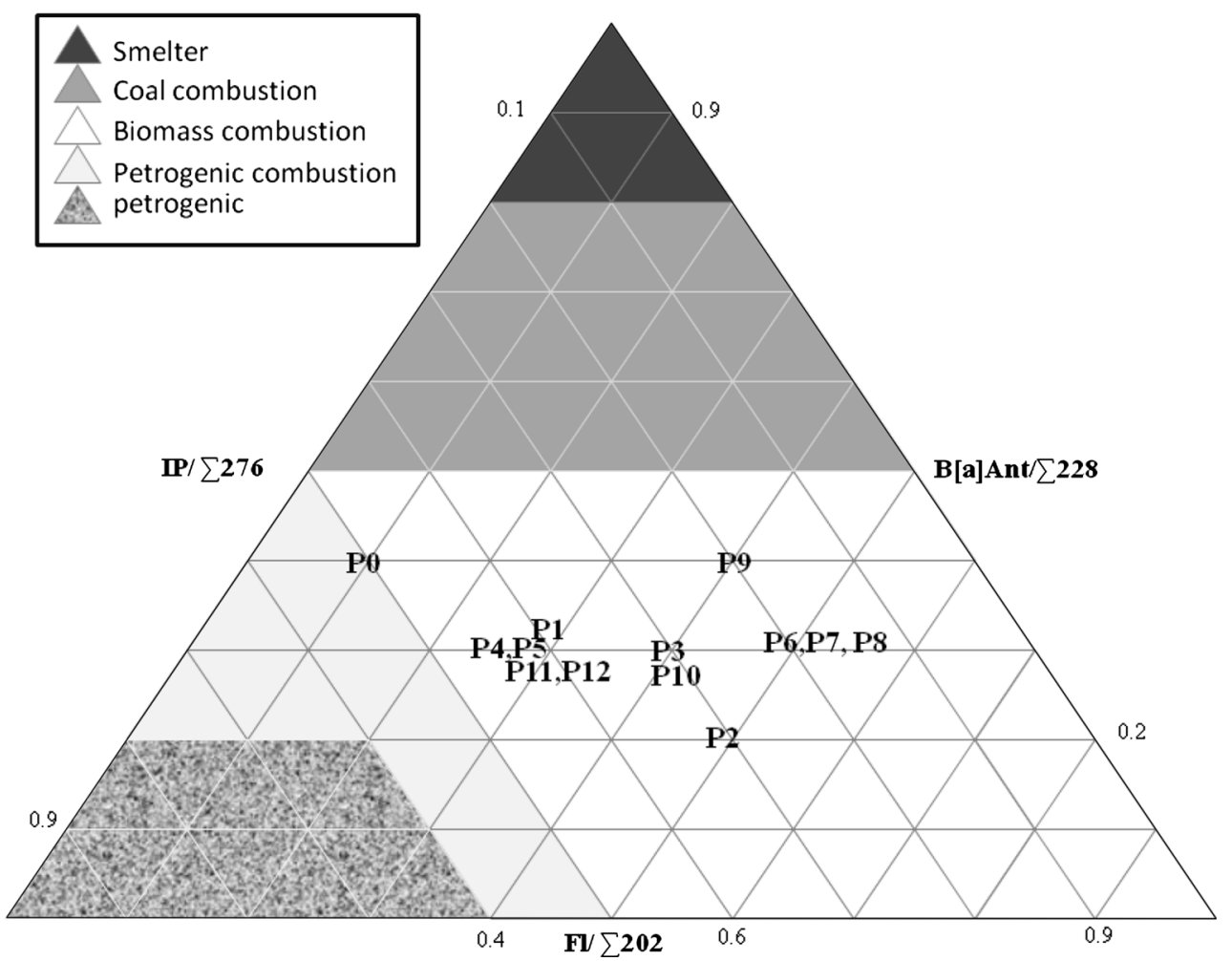

sediments (average for P1-P12 was 0.53 ) compared to P0 (0.31) (Table 4); the findings, however, cannot determine whether the remaining LABs consisted of partially transformed degradation products (i.e., intermediates that could not have been used as carbon sources by the microorganisms present) or remaining LAB homologs that could not be transformed by the microbial population. In this sense, some environmental processes might change $\mathrm{I} / \mathrm{E}$ ratios during transport when we compared low I/E ratios in the WWTP sewerage canal and slight improvement seaward (P1-P12). In a partial conclusion, the present study demonstrated the usefulness of I/E ratio to evaluate the effectiveness of sewage treatment systems showing by the lower value of I/E at P0 but application of such ratios to the other transitional area should be applied with caution because of its complexity interaction i.e., biotic and abiotic factors.

\section{Correlation with organic matter}

Total carbon and TOC were measured in the Cortiou sediments. TC varied from 0.072 to $0.129 \mathrm{mg} \mathrm{C} \mathrm{mg}^{-1}$ sediment, and TOC ranged from 0.005 to $0.089 \mathrm{mg} \mathrm{C} \mathrm{mg}^{-1}$ sediment. TOC represented $6.2-68.7 \%$ of TC. The analysis of variance (ANOVA) and linear regression were employed to compare differences in $\sum n$-alkane, $\sum$ PAHs and $\sum$ LABs with the physicochemical properties (EOM, TC and TOC) in the surface sediments of Cortiou and to explore correlations between those parameters (Table 5).
The regression analysis exhibited that the sum PAHs concentration had significant correlations with MOE and TOC in surface sediments $(p<0.05, n=13)$, while the total 16 priority PAHs did not show any statistically significant correlations with TC properties of the surface sediments (Table 5). Our finding is in accordance with the previous studies that demonstrated good linear relationships between total PAHs and organic matter content in surface sediments (Viguri et al. 2002; Wang et al. 2011), but in contrary with Hung et al. (2010, 2011) who argued that PAHs can more easily be affected by black carbon as compared to organic matter. Despite the fact that study area is also affected by repeated fires (Vernoux et al. 2011), the sedimentary PAHs in the study area are not exclusively pyrolytic, and association of soot carbon (as part of TC) with planar surface of polyaromatic soot might be lower (Hung et al. 2010). Interestingly, the $n$-alkanes and LABs showed the opposite, correlating with TC significantly stronger than PAHs. A possible explanation is that the distribution of $n$-alkanes and LABs in the surface sediments might relate to input sources (biogenic terrestrial) reflecting by TC (i.e., soot carbon) rather than bulk organic sediment. Therefore, this finding suggests that these three classes of pollutants might not be derived from the same source.

The poor correlations between target pollutants and the sediment properties were not expected. P7-P9 had higher TOC levels (4.9-8.8\%) than those in other sites close to 
Table 4 Identification and quantification of LABs in Cortiou sediments $\left(\mu \mathrm{g} \mathrm{kg}^{-1}\right)$

\begin{tabular}{|c|c|c|c|c|c|c|c|c|c|c|c|c|c|c|}
\hline LAB & P0 & PI & $\mathrm{P} 2$ & P3 & P4 & P5 & P6 & P7 & P8 & P9 & $\mathrm{P} 10$ & P11 & $\mathrm{P} 12$ & Average (P1-P12) \\
\hline $\begin{array}{r}5-C_{10^{-}} \\
\text {LAB }\end{array}$ & 4.9 & 7.7 & 6.4 & 11.8 & 67.7 & 32.1 & 39.4 & 28.0 & 24.4 & 0.0 & 1.8 & 3.3 & 12.3 & 19.6 \\
\hline $\begin{array}{r}4-\mathrm{C}_{10^{-}} \\
\mathrm{LAB}\end{array}$ & 6.4 & 3.8 & 3.1 & 6.2 & 27.5 & 12.6 & 14.1 & 14.8 & 2.6 & 7.9 & 0.9 & 1.9 & 6.3 & 8.5 \\
\hline $\begin{array}{r}3-\mathrm{C}_{10^{-}} \\
\mathrm{LAB}\end{array}$ & 4.3 & 2.7 & 1.9 & 4.7 & 16.4 & 8.5 & 7.7 & 6.3 & 2.2 & 4.8 & 0.7 & 1.5 & 4.5 & 5.2 \\
\hline $\begin{array}{r}2-C_{10^{-}} \\
\mathrm{LAB}\end{array}$ & 7.8 & 9.4 & 7.6 & 15.0 & 62.9 & 44.0 & 59.0 & 4.1 & 1.3 & 3.5 & 3.8 & 5.2 & 13.9 & 19.1 \\
\hline $\begin{array}{r}5-\mathrm{C}_{11^{-}} \\
\mathrm{LAB}\end{array}$ & 14.2 & 11.1 & 8.3 & 17.4 & 64.8 & 43.6 & 55.4 & 16.9 & 4.7 & 14.3 & 4.1 & 6.4 & 15.3 & 21.9 \\
\hline $\begin{array}{r}4-C_{11^{-}} \\
\text {LAB }\end{array}$ & 12.3 & 7.1 & 5.4 & 12.0 & 38.3 & 26.1 & 30.6 & 17.5 & 3.6 & 15.0 & 2.8 & 4.4 & 11.0 & 14.5 \\
\hline $\begin{array}{r}2-\mathrm{C}_{11^{-}} \\
\mathrm{LAB}\end{array}$ & 9.2 & 5.7 & 4.1 & 9.0 & 21.9 & 13.9 & 14.1 & 9.8 & 2.6 & 11.0 & 2.1 & 3.2 & 23.4 & 10.1 \\
\hline $\begin{array}{r}5-\mathrm{C}_{12^{-}} \\
\mathrm{LAB}\end{array}$ & 13.5 & 18.0 & 15.1 & 28.7 & 85.8 & 67.3 & 85.3 & 3.0 & 0.6 & 3.6 & 10.1 & 11.5 & 15.4 & 28.7 \\
\hline $\begin{array}{r}4-\mathrm{C}_{12^{-}} \\
\mathrm{LAB}\end{array}$ & 22.8 & 11.8 & 9.6 & 19.2 & 50.4 & 39.7 & 47.9 & 32.5 & 9.4 & 30.0 & 6.8 & 7.9 & 11.7 & 23.1 \\
\hline $\begin{array}{r}3-\mathrm{C}_{12^{-}} \\
\mathrm{LAB}\end{array}$ & 14.3 & 9.1 & 6.9 & 14.7 & 33.3 & 26.6 & 30.0 & 17.2 & 4.8 & 16.7 & 5.5 & 6.1 & 2.0 & 14.4 \\
\hline $\begin{array}{r}2-\mathrm{C}_{12^{-}} \\
\mathrm{LAB}\end{array}$ & 6.1 & 7.6 & 5.2 & 14.3 & 33.3 & 26.6 & 12.0 & 3.0 & 0.7 & 0 & 4.4 & 5.9 & 8.7 & 10.1 \\
\hline$\sum L A B$ & 115.8 & 94.1 & 73.6 & 153.4 & 502.3 & 341.1 & 395.6 & 153 & 56.9 & 106.8 & 42.9 & 57.3 & 124.2 & 175.1 \\
\hline $\mathrm{I} / \mathrm{E}^{*}$ & 0.31 & 0.63 & 0.7 & 0.59 & 0.73 & 0.72 & 0.95 & 0.06 & 0.04 & 0.08 & 0.6 & 0.58 & 0.70 & 0.53 \\
\hline
\end{tabular}

$* \mathrm{I} / \mathrm{E}=\sum\left(6-, 5-\mathrm{C}_{12} \mathrm{AB}\right) \sum\left(4-, 3-, 2-\mathrm{C}_{12} \mathrm{AB}\right) . \mathrm{LAB}=$ Linear alkyl benzene

Cortiou (0.5-3.1\%). Disregarding data from P7 to P9 resulted in better correlations between pollutants and the sediment properties (MOE, TC and TOC). From Electronic Supplementary Material, Fig. A, we can observe a zone highly perturbed in the $600-800 \mathrm{~m}$ from coastal (corresponds to P7-P9). Moreover, Vousdoukas et al. (2011) deployed oceanographical data collection system in this area for a period of 2-3 months and recorded several suspension and erosion events that have been identified when significant wave heights exceeding $1.5 \mathrm{~m}$.

Due to their hydrophobicity, $n$-alkanes and LABs are expected to have positive correlations with organic matter content. For instance, when the data for P7-P9 were excluded, the adjusted determination coefficients of MOE correlate significantly with $\sum n$-alkanes, $\sum$ LABs and total $\sum$ PAHs by value $0.151,0.694$ and 0.419 , respectively. More robust relationships were observed for $\sum n$-alkanes, $\sum$ LABs and $\sum$ PAHs with TOC showing the value 0.473 , 0.596 and 0.6333 , respectively. Regarding the TC, only the $\sum n$-alkanes exhibit significant correlations, confirming sources input hypothesis. Accordingly, P7-P9 might correspond to a hydrodynamically disturbed zone related to the mixing processes of the two different water masses. Hung et al. (2007) found similar distribution for different persistent organic pollutants in the Danshui River estuary and adjacent coastal area in Taiwan. In fact, as suggested by Hung et al. (2006), such random distribution may be due to irregular riverine input or wastewater plant discharge; tidal amplitude or residence times of the coastal water may affect these pollutant distributions rather than the source input, excepted for the $n$-alkanes in our case.

\section{Environmental significance}

Due to their bioaccumulation and biomagnification potentials, the occurrence and fate of sedimentary hydrocarbons in the environment is of particular interest. Generally, $n$ alkanes are not of much toxicological concern and are not reported to possess carcinogenic, teratogenic or mutagenic properties (Bellas et al. 2011). No information is available to date for $n$-alkane sediment quality standard criteria and benchmarks related to protection of aquatic biota. PAHs, however, are described as toxic, and some aromatics are potentially carcinogenic (Long and Morgan 1990). The effects of range-low (ERL) values (Burton et al. 2002) were considered in evaluating the possible ecotoxicological risks of PAHs in the study area. The measured concentrations of PAHs were then compared with their ERL levels. More than $40 \%$ of stations (P2-P7) exhibited contamination levels higher than ERL values $\left(3,500 \mu \mathrm{g} \mathrm{kg}^{-1}\right)$, indicating an $85 \%$ likelihood that sediment will cause an adverse effect to the sedimentary biota. Threshold effect 
Table 5 Adjusted determination coefficient $\left(\mathrm{r}^{2}\right)$ for categorical compounds (n-alkanes, PAHs and LABs) with MOE, TC and TOC in Cortiou sediments

\begin{tabular}{|c|c|c|c|c|c|c|c|c|c|}
\hline & \multicolumn{3}{|l|}{ MOE } & \multicolumn{3}{|l|}{ TC } & \multicolumn{3}{|l|}{ TOC } \\
\hline & $\mathrm{F}$ & $\mathrm{P}$ & Adjusted $r^{2}$ & $\mathrm{~F}$ & $\mathrm{P}$ & Adjusted $r^{2}$ & F & $\mathrm{P}$ & Adjusted $r^{2}$ \\
\hline$\sum$ n-alkanes & 0.0138 & 0.904 & 0 & 2.785 & 0.123 & 0.129 & 0.0611 & 0.809 & 0 \\
\hline$\sum \mathrm{LABs}$ & 0.0009 & 0.977 & 0 & 1.565 & 0.237 & 0.045 & 0.0163 & 0.901 & 0 \\
\hline$\sum$ PAHs & 6.442 & 0.028 & 0.312 & 0.28 & 0.607 & 0 & 2.798 & 0.123 & 0.13 \\
\hline \multicolumn{10}{|c|}{ Calculation without taking into account the data from P7-P9 } \\
\hline$\sum$ n-alkanes & 2.603 & 0.145 & 0.151 & 2.779 & 0.134 & 0.165 & 9.076 & 0.017 & 0.473 \\
\hline$\sum \mathrm{LABs}$ & 21.456 & 0.002 & 0.694 & 0.567 & 0.473 & 0 & 14.235 & 0.005 & 0.596 \\
\hline$\sum \mathrm{PAHs}$ & 7.49 & 0.026 & 0.419 & 0.157 & 0.702 & 0 & 16.551 & 0.004 & 0.633 \\
\hline
\end{tabular}

Bold character was regarded as being significant for all the tests

$P A H$ polycyclic aromatic hydrocarbons, $L A B s$ linear alkyl benzenes, MOE material organic extractable, TC total carbon, TOC total organic carbon

level (TEL) values represent the concentrations below which adverse effects are expected to occur only rarely for PAHs in sediments. The remaining $60 \%$ stations exceeded the TEL value of $870 \mu \mathrm{g} \mathrm{kg}^{-1}$ (Peters et al. 1999). Levels in sediments collected at stations P1 and P9-P12 ranged between the TEL and ERL benchmarks, suggesting probable adverse effects. Peters et al. (1999) noted that benzo[a]pyrene is used to assess the toxicities of other PAHs expressed as toxic equivalency factors (TEFs). According to the US Environmental Protection Agency (US EPA 1993), TEFs for benzo[a]anthracene, benzo[a]pyrene, benzo[b]fluoranthene, benzo[k]fluoranthene, indeno[1,2,3cd]pyrene and dibenzo[a,h]anthracene are $0.1,1,0.1,0.01$, 0.1 and 1, respectively. Sprovieri et al. (2007) proposed total concentrations of potentially carcinogenic PAHs (CPAHs), which consist of benzo[a]anthracenes, benzofluoranthenes, benzo[a]pyrenes, indeno[1,2,3-cd]pyrenes and dibenzo $[a, h]$ anthracenes. The values varied from 163 to $3,801 \mu \mathrm{g} \mathrm{kg}^{-1}$ and accounted for $20-60 \%$ of PAHs in sediments from Cortiou (Table 3). The unreacted residual LABs are discharged to coastal areas almost exclusively from sewage outfalls and are considered reliable sewage tracers (Peters et al. 1999). Following exposure assessments, the environmental risk characterizations of LABs for biota in the aquatic, terrestrial and soil categories were extensively evaluated by the European Council for Commission Regulation (EC) 1488/94. The report concluded that there are no concerns today for the environment or human health.

\section{Conclusion}

The calculated hydrocarbon indexes suggest that terrestrial biogenic inputs are the main sources of $n$-alkanes while pyrolytic sources derived from wood and biomass combustion contribute to the PAHs in surface sediments with the exception for $\mathrm{P} 0$, which can be origin of petrogenic. High hydrocarbon levels were generally found in the areas associated with high human impacts and harbor activities in the bay. LABs, which were used as a tracer of anthropogenic pollution in Cortiou sediments, were detected at the whole sampling locations. P0 I/E ratio (the ratios of internal isomers to external isomers in LABs) was low, suggesting that inadequately treated sewage is discharged into the marine environment. More after, low I/E ratios followed by C13-LABs and 6-C12-LABs in sediments with high total LAB concentrations suggest that a biodegradation process may take place concomitantly with a continually heavy load of untreated sewage. Thus, regular monitoring of LABs could provide an effective tool to assess the effectiveness of the implementation of sewage treatment systems. The high contaminant levels followed by a cumulative concentration of several toxic compounds may increase overall sediment toxicity. Thus, these findings highlight the necessity of continued environmental monitoring to assess sewage pollution release in coastal areas and determine the level of improvement of one of the "biggest" WWTPs in the world (Géolide). It is necessary to avoid future contaminant discharge into the National Park to ensure a better marine environment.

Acknowledgments This work was supported by the ANR project MARSECO (2008 CESA 018) in the framework of the research federation ECCOREV. The authors express their gratitude to the anonymous referees for their constructive comments. We are grateful to De F. Valroger and D. Eric for assistance with diving for sediment sampling and to N. Marriner for assessing English revisions. We also thank M. Bresson and J. F. Barbion for their assistance during sampling trips. The first author acknowledges Grants-in-Aid from the National Ministry of Education of Indonesia (DIKTI and BPKLN Kemdiknas Grants). 


\section{References}

Asia L, Mazouz S, Guiliano M, Doumenq P, Mille G (2009) Occurrence and distribution of hydrocarbons in surface sediments from Marseille Bay (France). Mar Pollut Bull 58:424-455

Baumard P, Budzinski H, Garrigues P (1998) Polycyclic aromatic hydrocarbons (PAHs) in sediments and mussels of the western Mediterranean Sea. Environ Toxicol Chem 17:765-776

Bayona JM, Albaiges J, Solanas AM, Grifoll M (1986) Selective aerobic degradation of linear alkylbenzenes by pure microbial cultures. Chemosphere 15:595-598

Bellas J, Nieto O, Beiras R (2011) Integrative assessment of coastal pollution: development and evaluation of sediment quality criteria from chemical contamination and ecotoxicological data. Cont Shelf Res 31:448-456

Benner R, Strom M (1993) A critical evaluation of the analytical blank associated with DOC measurements by high-temperature catalytic oxidation. Mar Chem 41:153-160

Blumer M (1957) Removal of elemental sulfur from hydrocarbon fractions. Anal Chem 29:1039-1041

Bourbonniere RA, Meyers PA (1996) Sedimentary geolipid records of historical changes in the watersheds and productivities of Lakes Ontario and Erie. Limnol Oceanogr 41:352-359

Budzinski H, Jones I, Bellocq J, Piérard C, Garrigues P (1997) Evaluation of sediment contamination by polycyclic aromatic hydrocarbons in the Gironde estuary. Mar Chem 58:85-97

Burton GA Jr, Batley GE, Chapman PM, Forbes VE, Smith EP, Reynoldson T, Schlekat CE, den Besten PJ, Bailer AJ, Green AS, Dwyer RL (2002) A weight-of-evidence framework for assessing sediment (or other) contamination: improving certainty in the decision-making process. Hum Ecol Risk Assess $8: 1675-1696$

Cavalli L, Gellera A, Landone A (1993) LAS removal and biodegradation in a wastewater treatment plant. Environ Toxicol Chem 12:1777-1788

Deng W, Li CG, Li SY, Ma YY, Zhang DH (2013) Source apportionment of polycyclic aromatic hydrocarbons in surface sediment of mud areas in the East China Sea using diagnostic ratios and factor analysis. Mar Pollut Bull 70:266-273

Eganhouse RP, Pontolillo J (2008) Susceptibility of synthetic longchain alkylbenzenes to degradation in reducing marine sediments. Environ Sci Technol 42:6361-6368

Eganhouse RP, Sherblom PM (2001) Anthropogenic organic contaminant in the effluent of a combined sewer overflow: impact on Boston Harbor. Mar Environ Res 51:51-74

Fromme H, Lahrz T, Piloty M, Gebhardt H (2004) Polycyclic aromatic hydrocarbons inside and outside of apartments in an urban area. Sci Total Environ 326:143-149

Gledhill W, Saeger VW, Trehy ML (1991) An aquatic environmental safety assessment of linear alkylbenzene. Environ Toxicol Chem 10:169-178

Gordon AK, Muller WJ, Gysman N, Marshall SJ, Sparham CJ, O'Connor SM, Whelan MJ (2009) Effect of laundry activities on in-stream concentrations of linear alkylbenzene sulfonate in a small rural South African river. Sci Total Environ 407:4465-4471

Gustafsson O, Long CM, Macfarlane J, Gschwend PM (2001) Fate of linear alkylbenzenes released to the coastal environment near Boston Harbor. Environ Sci Technol 35:2040-2048

Harkov R, Kebbekus B, Bozzelli JW, Lioy PJ, Daisey J (1984) Comparison of selected volatile organic compounds during the summer and winter at urban sites in New Jersey. Sci Total Environ 38:259-274

Hartmann PC, Quinn JG, Cairns RW, King JW (2004) The distribution and sources of polycyclic aromatic hydrocarbons in Narragansett Bay surface sediments. Mar Pollut Bull 48:351-358

HERA (2007) HERA-LAS Human and Environmental Risk Assessment: Linear Alkylbenzene Sulphonates. LAS. CAS No. 68411-30-3, Version 3.0, Oct 2007. http://www.heraproject.com

Hinga KR (2003) Degradation rates of low molecular weight PAH correlate with sediment TOC in marine subtidal sediments. Mar Pollut Bull 46:466-474

Hung CC, Gong GC, Jiann KT, Yeager KM, Santschi PH, Wade TL, Sericano JL, Hsieh HL (2006) Relationship between carbonaceous materials and polychlorinated biphenyls ( $\mathrm{PCBs})$ in the sediments of the Danshui River and adjacent coastal areas, Taiwan. Chemosphere 65:1452-1461

Hung CC, Gong GC, Chen HY, Hsieh HL, Santschi PH, Wade TL, Sericano JL (2007) Relationships between pesticides and organic carbon fractions in sediments of the Danshui River estuary and adjacent coastal areas of Taiwan. Environ Pollut 148:546-554

Hung CC, Gong GC, Ko FC, Chen HY, Hsu ML, Wu JM, Peng SC, Nan FH, Yeager KM, Santschi PH (2010) Relationships between persistent organic pollutants and carbonaceous materials in aquatic sediments of Taiwan. Mar Pollut Bull 60:1010-1017

Hung CC, Gong GC, Ko FC, Lee HY, Chen HY, Wu JM, Hsu ML, Peng SC, Nan FH, Santschi PH (2011) Polycyclic aromatic hydrocarbons in surface sediments of the East China Sea and their relationship with carbonaceous materials. Mar Pollut Bull 63:464-470

Inengite AK, Oforka NC, Leo CO (2013) Source identification of polycyclic aromatic hydrocarbons in sediments of a creek around a flow station. Int J Environ Sci Technol 10(3):519-532

Ishiwatari R, Takada H, Yun SJ, Matsumoto E (1983) Alkylbenzene pollution of Tokyo Bay sediments. Nature 301:599-600

Isobe KO, Zakaria MP, Chiem NH, Minh LY, Prudente M, Boonyatumanond R, Saha M, Sarkar S, Takada H (2004) Distribution of linear alkylbenzenes (LABs) in riverine and coastal environments in South and Southeast Asia. Water Res 38:2449-2459

Jeng WL (2006) Higher plant $n$-alkane average chain length as an indicator of petrogenic hydrocarbon contamination in marine sediments. Mar Chem 102:242-251

Kanzari F, Syakti AD, Asia L, Malleret L, Mille G, Jamoussi B, Abdelrrabba M, Doumenq P (2012) Aliphatic hydrocarbons, polycyclic aromatic hydrocarbons, polychlorinated biphenyls (PCBs), organochlorine and organophosphorous pesticides in surface sediments from the Arc River and the Berre Lagoon, France. Environ Sci Pollut Res 19(2):559-576

Léon VM, Gonzalez-Mazo E, Gomez-Parra A (2000) Handling of marine and estuarine samples for the determination of linear alkylbenzene sulfonates and sulfophenylcarboxylic acids. J Chromatogr A 889:211-219

Liu X, Jia H, Wang L, Qi H, Ma W, Hong W, Guo J, Yang M, Sun Y, Li YF (2013) Characterization of polycyclic aromatic hydrocarbons in concurrently monitored surface seawater and sediment along Dalian coast after oil spill. Ecotoxicol Environ Saf 90:151-156

Long ER, Morgan LG (1990) The potential for biological effects of sediment-sorbed contaminants tested in the National Status and Trends Program. NOAA Technical Memorandum NOS OMA 52. NOAA Office of Oceanography and Marine Assessment, Seattle, WA, p 220

Luo XJ, Chen SJ, Ni HG, Yu M, Mai BX (2008) Tracing sewage pollution in the Pearl River Delta and its adjacent coastal area of South China Sea using linear alkylbenzenes (LABs). Mar Pollut Bull 56:158-162

Micic V, Kruge M, Komer P, Bujalski N, Hofmann T (2010) Organic geochemistry of Danube River sediments from Pančevo (Serbia) 
to the Iron Gate dam (Serbia-Romania). Org Geochem 41:971-974

Mille G, Asia L, Guiliano M, Malleret L, Doumenq P (2007) Hydrocarbons in coastal sediments from the Mediterranean sea (Gulf of Fos area, France). Mar Pollut Bull 54:566-575

Mungray AK, Kumar P (2009) Fate of linear alkylbenzene sulfonates in the environment: a review. Int Biodeterior Biodegradation 63:981-987

Murray AP, Gibbs CF, Kavanagh PE (1987) Linear alkylbenzenes (LABs) in sediments of Port Phillip Bay (Australia). Mar Environ Res 23:65-76

Olivella MA, Ribalta TG, de Febrer AR, Mollet JM, de Las Heras FX (2006) Distribution of polycyclic aromatic hydrocarbons in riverine waters after Mediterranean forest fires. Sci Total Environ 355:156-166

Page DS, Boehm PD, Douglas GS, Bence AE, Burns WA, Mankiewicz PJ (1999) Pyrogenic polycyclic aromatic hydrocarbons in sediments record past human activity: a case study in Prince William Sound, Alaska. Mar Pollut Bull 38:247-260

Peters CA, Knightes KD, Brown DG (1999) Long-term composition dynamics of PAH-containing NAPLs and implications for risk assessment. Environ Sci Technol 33:4499-4507

Rico-Rico A, Temara A, Behrends T, Hermens JLM (2009) Effect of sediment properties on the sorption of $\mathrm{C}_{12}$-2-LAS in marine and estuarine sediments original. Environ Pollut 157:377-383

Schutzendubel A, Majcherczyk A, Johannes C, Hüttermann A (1999) Degradation of fluorene, anthracene, phenanthrene, fluoranthene, and pyrene lacks connection to the production of extracellular enzymes by Pleurotus ostreatus and Bjerkandera adusta. Int Biodeterior Biodegradation 43:93-100

Sikes EL, Uhle ME, Nodder SD, Howard ME (2009) Sources of organic matter in a coastal marine environment: evidence from $n$-alkanes and their $\delta 13 \mathrm{C}$ distributions in the Hauraki Gulf, New Zealand. Mar Chem 113:149-163

Sprovieri M, Feo ML, Prevedello L, Manta DS, Sammartino S, Tamburrino S, Marsella E (2007) Heavy metals, polycyclic aromatic hydrocarbons and polychlorinated biphenyls in surface sediments of the Naples harbour (southern Italy). Chemosphere 67:998-1009

Syakti AD, Hidayati NV, Hilmi E, Piram A, Doumenq P (2013) Source apportionment of sedimentary hydrocarbons in the
Segara Anakan Nature Reserve, Indonesia. Mar Pollut Bull 74:141-148

Tao S, Li X, Yang Y Jr, Coveney RM, Lu X, Chen H, Shen W (2006) Dispersion modeling of polycyclic aromatic hydrocarbons from combustion of biomass and fossil fuels and production of coke in Tianjin, China. Environ Sci Technol 40:4586-4591

Tao S, Liu YN, Xu W, Lang C, Liu SZ, Dou H, Liu WX (2007) Calibration of a passive sampler for both gaseous and particulate phase polycyclic aromatic hydrocarbons. Environ Sci Technol 41:568-573

US Environmental Protection Agency (US EPA) (1993) Provisional guidance for quantitative risk assessment of polycyclic aromatic hydrocarbons. EPAy600yRy089. Office of Research and Development, US EPA, Washington, DC

Vernoux A, Malleret L, Asia L, Doumenq P, Theraulaz F (2011) Impact of forest fires on PAH level and distribution in soils. Environ Res 111:193-198

Viguri J, Verde J, Irabien A (2002) Environmental assessment of polycyclic aromatic hydrocarbons (PAHs) in surface sediments of the Santander Bay, Northern Spain. Chemosphere 48:157-165

Volkman JK, Revill AT, Holdsworth DG, Frederick D (2008) Organic matter sources in an enclosed coastal inlet assessed using lipid biomarkers and stable isotopes. Org Geochem 39:689-710

Vousdoukas MI, Verney R, Dufois F, Pinazo C, Sauzade D, Meule S, Cann P, Plomaritis TA (2011) Sediment dynamics in the Bay of Marseille, Gulf of Lions (France): hydrodynamic Forcing vs. Bed Erodibility. J Coast Res 27:942-958

Wagener ALR, Meniconi MFG, Hamacher C, Farias CO, da Silva GC, Gabardo IT, Scofield AL (2012) Hydrocarbons in sediments of a chronically contaminated bay: the challenge of source assignment. Mar Pollut Bull 64:284-294

Wang XC, Zhang YX, Chen RF (2011) Distribution and partitioning of polyaromatic hydrocarbons (PAHs) in different size fractions in sediments from Boston Harbor, United States. Mar Pollut Bull 42:1139-1149

Yunker MB, Macdonald RW, Vingarzan R, Mitchell RH, Goyette D, Sylvestre S (2002) PAHs in the Fraser River basin: a critical appraisal of PAH ratios indicators of PAH source and composition. Org Geochem 33:489-515 